\title{
Evaluation of the probiotic attributes of Bacillus strains isolated from traditional fermented African locust bean seeds (Parkia biglobosa), "daddawa"
}

\author{
Tochukwu Nwamaka Nwagu*, Chika Jude Ugwuodo, Chukwudi O. Onwosi, Ogechukwu Inyima, \\ Oluoma Chizaram Uchendu and Chioma Akpuru
}

\begin{abstract}
Background: The involvement of probiotic cultures in food fermentation guarantees enhanced organoleptic properties and maximum consumer health benefits. In this study, isolated Bacillus cultures used in the fermentation of African locust bean seeds "Parkia biglobosa" into the food condiment "daddawa" were evaluated for probiotic attributes. Bacillus cereus strains $\mathrm{BC} 1$ and $\mathrm{BC} 2$ were tested for tolerance to acid, common salt $(\mathrm{NaCl})$, and bile salt. Auto-aggregation and adhesion to epithelial cells, antibiotic sensitivity profile, hemolytic pattern, and antibacterial activity were also evaluated. To demonstrate further health benefit, spores of strain $\mathrm{BC} 1$ were investigated for antiinflammatory potential employing the rat paw edema technique.

Results: Both Bacillus cereus strains showed antagonistic activity against pathogenic Escherichia coli and Staphylococcus aureus. BC1 was more acid-stress tolerant than BC2, maintaining 107.6\% viability after $3 \mathrm{~h}$ incubation in MRS broth of $\mathrm{pH}$ 2.5. However, at $97.74 \%$ viability after incubation for $3 \mathrm{~h}, \mathrm{BC} 2$ was more tolerant to $0.4 \%$ bile salt. The Bacillus cereus strains were susceptible to all antibiotics tested with the exception of norfloxacin and thrived under high saline stress. Both strains were protease producers and non-hemolytic on sheep blood agar. The edema inhibition study revealed that spores of Bacillus cereus strain BC1 had anti-inflammation potential and produced no physiological toxicity on the animals.

Conclusion: These results indicate that the Bacillus cultures for "daddawa" production are good candidates for probiotics and have the potential for application in both animal and human formulations for increased health benefit to consumers.
\end{abstract}

Keywords: Probiotic, Daddawa, Bacillus, Parkia biglobosa, Food quality, African locust bean

\section{Background}

Fermented foods abound in the native African cuisine either as main course meals, beverages, or food condiments, and in most cases, constitute the main source of nutrition for the rural dwellers. These foods are fermented with no prior knowledge of the exact microbial population, diversity and succession, or their individual roles during

\footnotetext{
*Correspondence: tochukwu.nwagu@unn.edu.ng

Department of Microbiology, University of Nigeria, Nsukka, Nigeria
}

fermentation; many are either contaminants or pathogens, serving minor/major roles in fermentation without any probiotic quality or effect (Franz et al. 2014). One major class of these fermented foods is the legume-based fermented foods such as ugba (Nwagu et al. 2011), daddawa (Ezeokoli et al. 2018), and okpeye (Oguntoyinbo et al. 2007). Bacillus species are widely documented as primary agents in the alkaline fermentation of these legumes (Tamang et al. 2016). However, there is paucity of studies on the possible probiotic quality of these foods or the probiotic nature of the

(c) The Author(s). 2020 Open Access This article is licensed under a Creative Commons Attribution 4.0 International License, which permits use, sharing, adaptation, distribution and reproduction in any medium or format, as long as you give appropriate credit to the original author(s) and the source, provide a link to the Creative Commons licence, and indicate if changes were made. The images or other third party material in this article are included in the article's Creative Commons licence, unless indicated otherwise in a credit line to the material. If material is not included in the article's Creative Commons licence and your intended use is not permitted by statutory regulation or exceeds the permitted use, you will need to obtain permission directly from the copyright holder. To view a copy of this licence, visit http://creativecommons.org/licenses/by/4.0/. 
microbial strains actively involved in their fermentation especially Bacillus.

Probiotics have been defined as "live microorganisms that when administered in adequate amounts, confer health benefit to the host" (FAO/WHO 2002; Hill et al. 2014). A lot remains to be unraveled about probiotic microorganism, their sources, role in the biological system, and mode of function. This is due to the importance of this group of organisms, their versatility in numerous fermented foods and healthy human systems, and also their enormous health benefits whether in preventive (Horosheva et al. 2014), or in promotive and curative (Sazawal et al. 2006) health care. According to Burgain et al. (2011), probiotics represent about $65 \%$ of the global functional food market and have been incorporated into numerous foods amongst which are dairy and non-dairy products (chocolates, cereals and juices). Though probiotics are living organisms, dead bacteria and bioactive compounds produced by live cells can also exhibit probiotic qualities (Chugh and Kamal-Eldin 2020; Plaza-Diaz et al. 2019).

To qualify as a probiotic, a microbial strain must have the ability to exert beneficial effect on the host animal, e.g., increased growth or resistance to disease, be nonpathogenic and non-toxic, be found in the finished product as viable cells in large numbers, be able to survive and metabolize in the gut environment, and show stability in storage and field conditions. These properties are attributed to the ability of the microorganism to produce acids and/or bacteriocins, and other metabolites which not only have the capacity to boost the host immune systems but also favorably impacts its competitiveness against other microbes. Some probiotics are known to have the ability to stimulate, modulate, and regulate immune response in the host, modulate the release of hormones in the gastrointestinal tract (Kristensen et al. 2016), and regulate acute and chronic inflammation in intestinal mucosal tissue caused by inflammatory bowel disease (IBD) progression (Bakirtzi et al. 2016). In addition to the qualities mentioned above, the microorganism has to be microbiologically characterized and subjected to randomized clinical trials (Singh et al. 2011; Plaza-Diaz et al. 2019).

Contrary to what was previously thought (that probiotics consist of merely lactic acid bacteria), it is now common knowledge that other bacteria including Bacillus species, Clostridium and Escherichia coli, and even yeasts such as Saccharomyces species (S. cerevisiae and S. boulardii) possess probiotic qualities (Sanders et al. 2019). Due to the importance of probiotics to both humans and animals, researchers are constantly in search of new species/strains with more specific features as new probiotic candidates (Reid et al. 2019; Ryu and Chang 2013; Suez et al. 2019).

Bacillus species are Gram-positive spore formers, and some strains are known to have probiotic qualities
(Cutting 2011). Though not yet fully explored, Bacillus strains as probiotic agents have potential benefits over widely used LAB due to their higher acid tolerance and better stability during heat processing, drug formulation, and low temperature storage (Bader et al. 2012). This stability is due to their spores, known to survive extremely adverse conditions of growth and germinate when the environmental condition improves. The species of Bacillus that have been extensively examined for probiotic attributes include Bacillus subtilis, Bacillus clausii, Bacillus cereus, Bacillus coagulans, and Bacillus licheniformis (Cutting 2011). Spore probiotics are currently being used in humans as dietary supplements, in aquaculture, and in animals as growth promoters (Kuebutornye et al. 2019). Safety issues surround the use of Bacillus as probiotics. Some strains like Bacillus anthracis are pathogenic to humans. Another species, Bacillus cereus, appears to be a cause for concern on a case-by-case basis. In other words, there are probiotic/safe B. cereus strains (Cutting 2011; Zhao et al. 2016; Jiang et al. 2019), as well as pathogenic strains. Many works have reviewed the safety of Bacillus species (Lakshmi et al. 2017; Lefevre et al. 2017; Metlakunta and Soman 2020). Animal and in vitro toxicity studies on Bacillus subtilis CU1 (Lefevre et al. 2017), B. clausii UBBC07 (Lakshmi et al. 2017), Bacillus coagulans SNZ 1969 (Metlakunta and Soman 2020), and B. licheniformis 2336 (Sorokulova et al. 2008) indicated no adverse effects associated with use. According to the Qualified Presumption of Safety (QPS) adopted by the European Food Safety Authority (EFSA), for an organism to be considered safe for use as a probiotic, it must satisfy the following criteria: be identified at the strain and species level, lack the ability to transfer antimicrobial resistances, and lack toxigenic activity (Lefevre et al. 2017). In addition, human consumption studies are to be carried out to determine if the probiotic leads to the induction of any undesirable physiological effects (FAO/WHO 2002). However, before these safety evaluation protocols, studies to assess the probiotic attributes of the species is a required first step.

Bacillus cereus strains were isolated during the traditional fermentation of African locust bean (Pakia biglobosa) seeds for the production of "daddawa," an important food condiment in Nigeria and in many parts of West Africa and utilized as starter cultures for controlled fermentation of "daddawa." The current study evaluated the probiotic attributes of these Bacillus strains.

\section{Materials and methods Microorganism}

Two Bacillus cereus strains with accession numbers KY746353.1 and KX784915.1 earlier isolated in our 
laboratory as active agents in the traditional fermentation of "daddawa" and identified through molecular biology techniques were used in this study. B. cereus strain KY746353.1 had a similarity/E-score of $99.4 \%$ while $B$. cereus strain KX784915.1 had a similarity/E-score of $87 \%$. Both organisms were maintained on nutrient agar slants at $4{ }^{\circ} \mathrm{C}$ prior to use. Sterile MRS broth was inoculated with Bacillus and incubated at $37{ }^{\circ} \mathrm{C}$ for $24 \mathrm{~h}$, referred to in this study as " $24 \mathrm{~h}$ culture" or "overnight culture." This was used for some tests described below.

\section{Antibacterial activity}

Antibacterial activity was evaluated against pathogenic Klebsiella pneumoniae, Escherichia coli, and Staphylococcus aureus using a cut well assay diffusion method modified from Rokana et al. (2016). The pathogens were obtained from the stock culture of Medical Microbiology Laboratory, University of Nigeria, Nsukka. K. pneumoniae and $S$. aureus were separately grown in tryptic soy broth while $E$. coli was grown in nutrient broth. Aliquots of $100 \mu \mathrm{l}$ of the actively growing pathogenic strains were seeded in sterilized molten tryptic soy agar (for K. pneumoniae and S. aureus) and nutrient agar (for E. coli), and then dispensed into plates. Wells $(5 \mathrm{~mm})$ were punched in the agar plates using a sterile borer. Then, 1 $\mathrm{ml}$ aliquots of the cell free supernatants of overnightgrown cultures of the Bacillus strains were dispensed in separate wells. The agar plates were kept at $7{ }^{\circ} \mathrm{C}$ to allow the supernatants diffuse into the agar. They were then incubated in inverted position until inhibition zones appeared. The diameter of the zones was measured using a caliper.

\section{Auto-aggregation}

Auto-aggregation of the Bacillus cereus isolates was determined according to a modified method of Lee et al. (2016). Bacterial cells were collected from a 24-h culture by centrifugation at $10,000 \mathrm{rpm}$ for $10 \mathrm{~min}$. The cells were washed twice with phosphate buffered saline (PBS) and re-suspended with $3 \mathrm{ml}$ of PBS. The suspension was vortexed for $30 \mathrm{sec}$. Exactly, $0.1 \mathrm{ml}$ was taken from the upper layer of the suspension, mixed with $2.9 \mathrm{ml}$ of PBS, and the absorbance measured after $0,1,2$, and $3 \mathrm{~h}$ at $600 \mathrm{~nm}$ using a UV/visible spectrophotometer.

Auto-aggregation $(\%)=\left(1-A_{\mathrm{t}} / A_{0}\right) \times 100 ; A_{\mathrm{t}}=$ absorbance at 1,2 , and $3 \mathrm{~h}$ at $600 \mathrm{~nm}, A_{0}=$ absorbance at $0 \mathrm{~h}$ at $600 \mathrm{~nm}$.

\section{Antibiotic susceptibility}

To evaluate the antibiotic susceptibility of the Bacillus cereus strains, the method of Patel et al. (2009) was used. The fresh culture of the Bacillus sp. was streaked densely on Mueller-Hinton agar by a sterile cotton swab. Paper discs impregnated with streptomycin $(10 \mu \mathrm{g})$, erythromycin $(30 \mu \mathrm{g})$, ampiclox $(10 \mu \mathrm{g})$, rifampicin (30 $\mu \mathrm{g})$, norfloxacin $(30 \mu \mathrm{g})$, gentamicin $(10 \mu \mathrm{g})$, amoxil $(30$ $\mu \mathrm{g})$, and ciprofloxacin $(5 \mu \mathrm{g})$ were loaded on the plates. The diameters of the clear zones were measured after incubation for $48 \mathrm{~h}$ at $37^{\circ} \mathrm{C}$.

\section{Acid tolerance}

Following the method of Lee et al. (2013), a 2-ml aliquot of Bacillus cereus culture grown overnight in MRS broth was incubated in $10 \mathrm{ml}$ of freshly prepared MRS broth $(\mathrm{pH} 2.5)$ at $37{ }^{\circ} \mathrm{C}$. Samples were collected after various time intervals $(0-3 \mathrm{~h})$. After collection, each sample was spread onto MRS agar plates and incubated for $24 \mathrm{~h}$ at $37{ }^{\circ} \mathrm{C}$; then, viable cells were enumerated. The relative survival of the organisms was calculated with the formula below:

$$
\begin{aligned}
\text { Viability }(\%) & =\left[\frac{\mathrm{Nt}}{\mathrm{N} 0}\right] \times 100 ; N \mathrm{t} \\
& =\log \mathrm{CFU} \text { at intervals } 1,2, \text { and } 3 \mathrm{~h} \text { and } N 0 \\
& =\log \mathrm{CFU} \text { at } 0 \mathrm{~h}
\end{aligned}
$$

\section{Bile salt tolerance}

Bile salt tolerance of the Bacillus strains was determined using a slight modification of the method of Lee et al. (2013). A 2-ml aliquot of Bacillus culture grown overnight in MRS broth was incubated in $10 \mathrm{ml}$ of freshly prepared MRS broth containing $0.4 \%$ bile salt at $37{ }^{\circ} \mathrm{C}$ for $0-3 \mathrm{~h}$. After every hour, samples were collected and spread onto MRS agar plates using a glass rod, then incubated for $24 \mathrm{~h}$ at $37^{\circ} \mathrm{C}$, after which viable cells were counted. The relative survival of the organisms in the MRS broth containing $0.4 \%$ bile salt was calculated with the formula below:

$$
\begin{aligned}
\text { Viability }(\%) & =\left[\frac{\mathrm{Nt}}{\mathrm{N} 0}\right] \times 100 ; \mathrm{Nt} \\
& =\log \mathrm{CFU} \text { at intervals } 1,2 \text {, and } 3 \mathrm{~h} \text { and } N 0 \\
& =\log \mathrm{CFU} \text { at } 0 \mathrm{~h}
\end{aligned}
$$

\section{Cell hydrophobicity}

The cell hydrophobicity of the isolates was determined according to Lee et al. (2016). A 24-h culture was centrifuged at 10,000 rpm for $3 \mathrm{~min}$. The cells were washed twice with PBS and re-suspended with $2 \mathrm{ml}$ of PBS. Its absorbance was measured at $600 \mathrm{~nm}$ and this was used as the value of $A_{0}$ to determine hydrophobicity in percentage. Cell suspension was mixed separately with equal volumes of ethyl acetate and chloroform, then vortexed for $5 \mathrm{~min}$. The mixture was allowed to separate into two phases for $30 \mathrm{~min}$. Then, the absorbance of the aqueous phase was measured at $600 \mathrm{~nm}$ and used as the value of $A_{1}$. 
Hydrophobicity $(\%)=\left(1-A_{1} / A_{0}\right) \times 100$.

\section{Sodium chloride tolerance}

The method of Lee et al. (2013) was adapted for the determination of the level of tolerance to sodium chloride by the Bacillus cereus strains. Two milliliters of a 24-h culture was incubated in MRS broths containing varying percentages $(1,4,10$, and $15 \%) \mathrm{NaCl}$ for $24 \mathrm{~h}$ at $37^{\circ} \mathrm{C}$. Each sample was then spread onto MRS agar and viable cells counted.

Tolerance to sodium chloride was calculated as:

$$
\begin{aligned}
\text { Viability }(\%) & =\left[\frac{\mathrm{Nt}}{\mathrm{N} 0}\right] \times 100 ; N \mathrm{t} \\
& =\log \mathrm{CFU} \text { at } 24 \mathrm{~h} \text { and } N 0 \\
& =\log \mathrm{CFU} \text { at } 0 \mathrm{~h}
\end{aligned}
$$

\section{Amylase and protease production test}

For protease production, overnight culture (1\%) was added into the protease production medium containing $(\mathrm{g} / \mathrm{L})$ : casein, 10; glucose, 5.0; $\mathrm{MgSO} 4.7 \mathrm{H} 2 \mathrm{O}, 5.0$; $\mathrm{KH} 2 \mathrm{PO} 4,5.0$; and $\mathrm{FeSO} 4.7 \mathrm{H} 2 \mathrm{O}, 0.1$, and incubated at $37{ }^{\circ} \mathrm{C}$ for $24 \mathrm{~h}$. The culture was then centrifuged at 10 , $000 \mathrm{rpm}$ for $15 \mathrm{~min}$. The clear, cell-free supernatant was used for protease assay by a method modified from Nwagu et al. (2015).

For amylase production, a medium containing: soluble starch $(20 \mathrm{~g} / \mathrm{L})$, peptone $(5 \mathrm{~g} / \mathrm{L}),(\mathrm{NH} 4) 2 \mathrm{SO} 4(2 \mathrm{~g} / \mathrm{L})$, KH2PO4 $(1 \mathrm{~g} / \mathrm{L}), \mathrm{K} 2 \mathrm{HPO} 4(2 \mathrm{~g} / \mathrm{L})$, and $\mathrm{MgCl} 2(0.01 \mathrm{~g} /$ L) was inoculated with overnight grown bacterial culture. The inoculated medium was incubated at $37^{\circ} \mathrm{C}$ for $24 \mathrm{~h}$. After the incubation period, the culture medium was centrifuged at $10,000 \mathrm{rpm}$ for $15 \mathrm{~min}$ to obtain the crude enzyme extract. Amylase assay was carried out following the method of Bernfeld (1955) using 3,5-dinitrosalicylic acid.

\section{Hemolysis}

The Bacillus cereus strains were streaked on $7 \%$ sheep blood agar and incubated at $37^{\circ} \mathrm{C}$ for $48 \mathrm{~h}$ in line with Anand et al. (2000). The sheep blood was obtained aseptically from the Faculty of Veterinary Medicine Animal Research Laboratory, University of Nigeria, Nsukka. Isolates that formed a green zone around the colony were designated as alpha hemolytic while those that formed a clear zone were denoted as beta hemolytic.

\section{Phenol tolerance}

Phenol tolerance was determined by inoculating $100 \mu \mathrm{l}$ of 24 h-old Bacillus culture into MRS broth containing $0.2 \%$ and $0.5 \%$ of phenol. The optical density (OD) of the broths was measured at $600 \mathrm{~nm}$ before $(0 \mathrm{~h})$ and after $24 \mathrm{~h}$ of incubation. Values obtained were used to calculate viability (\%):

Viability $(\%)=\frac{O D_{24}}{O D_{0}} \times 100 ; O D_{24}=$ optical density at 24 $\mathrm{h}$ and $O D_{0}=$ optical density at $0 \mathrm{~h}$

\section{In vivo anti-inflammatory activity of spores of Bacillus BC1}

Spores of Bacillus spp. BC1 were produced by cultivating vegetative cells of the strain in a sporulation medium containing: $16 \mathrm{~g} / \mathrm{L}$ Difco nutrient broth, $2 \mathrm{~g} / \mathrm{L} \mathrm{KCl}$, and $0.7 \mathrm{~g} / \mathrm{L} \mathrm{MgSO} 4.7 \mathrm{H} 2 \mathrm{O}$ (Gashtasbi et al. 2014) for 1 week. After harvesting, the spores were treated to kill the vegetative cells, washed thrice, and stored in deionized water at freezing temperature. The spore suspension was adjusted to $10^{8}$ spores $/ \mathrm{ml}$.

The male Wistar rats (200-250 g) were housed in plastic shoe-box cages (4 per cage) with wire mesh tops, at the animal house facility of the Department of Biochemistry. The animal housing facility had restricted access. Softwood shavings were used as the bedding material. The animals had adequate access to conventional standard laboratory diet (corn, soybean pulp, shorts, bonquality flour, alfalfa pellets, molasses, meat and bone meal, poultry meal, sepiolite, inorganic DCP, marble dust, vitamins, minerals) bought from the Vital Feed Company and potable drinking water. The temperature of the housing facility was kept at room temperature, and the lighting cycle was $12 \mathrm{~h}$ light, $12 \mathrm{~h}$ dark. Their feeding behaviour was regularly monitored.

All experimental protocols were approved by the Ethics Committee, Faculty of Biological Sciences, University of Nigeria. Ethics Committee reference number for the study is UNN-IRB/FBS/2019_006. The animals were fed with food and water while they acclimatized for 1 week to the experimental environment.

To assess anti-inflammatory activity, animals were divided into two categories. Each category had the following groups $(n=4 /$ group$)$ :

1. Group 1 (negative control) received $500 \mu \mathrm{l}$ of distilled water orally.

2. Group 2 received $200 \mu \mathrm{l}$ of probiotic Bacillus spores suspension $\left(10^{8}\right.$ spores $\left./ \mathrm{ml}\right)$.

3. Group 3 received $500 \mu \mathrm{l}$ of probiotic Bacillus spores suspension $\left(10^{8}\right.$ spores $\left./ \mathrm{ml}\right)$.

4. Group 4 (positive control) received $150 \mathrm{mg} / \mathrm{kg}$ of diclofenac sodium.

Carrageenan-induced inflammation model of Sudjarwo (2005) was used to assess the anti-inflammatory potential of Bacillus $\mathrm{BC} 1$ spores. The Wistar rats in category one were orally administered with their respective treatments (vehicle, Bacillus spores, or diclofenac sodium); 
$30 \mathrm{~min}$ after, $100 \mu \mathrm{l}$ of freshly prepared carrageenan solution (1\%) was injected into the left hind paw of each rat. The extent of inflammation was monitored by measuring the paw thickness before and after injection of carrageenan at 0,4 , and $24 \mathrm{~h}$ with the help of a vernier caliper. A method modified from Solanki et al. (2015) was adopted and modified in evaluating the motility of the rats $24 \mathrm{~h}$ after carrageenan injection. The movement of the rats was observed for $5 \mathrm{~min}$ and scored on a scale of $0-5$ depending on the degree of movement: 0 , if it did not walk and 5 , if the rat moved about easily.

After the experiments, the animals were anaesthetized using chloroform $(300 \mu \mathrm{l}$ in a $500-\mathrm{ml}$ jar) by "drop jar" inhalation technique.

\section{Statistical analysis}

Data are expressed as mean \pm standard deviation of replicates. An analysis of variance (ANOVA) and Tukey's mean comparison test were performed to determine significant difference $(P<0.05)$ in the in vivo antiinflammatory activity test results using the Minitab 16.0 software. The $P$ values less than 0.05 were considered to be statistically significant.

\section{Results and discussion}

\section{Antibacterial activity}

Probiotic microorganisms including LAB, Bacillus species, Clostridium, and yeasts have been found in various fermented foods (Angmo et al. 2016); however, more researches have been done on LAB than any other group (Wang et al. 2016; Son et al. 2018). In this study, Bacillus cereus strains, KY746353.1 and KX784915.1 (henceforth referred as $\mathrm{BC} 1$ and $\mathrm{BC} 2$, respectively), isolated from traditional fermented "daddawa" were studied for antibacterial activity. Bacillus strains are antibacterial, antifungal, and antiviral (Sumi et al. 2015) though these properties are strain-specific. Bacillus cereus strains $\mathrm{BC} 1$ and $\mathrm{BC} 2$ showed antimicrobial activity against Escherichia coli, Klebsiella pneumoniae, and Staphylococcus aureus (Table 1). With inhibition zone diameters (IZDs) of $13 \mathrm{~mm}, 12 \mathrm{~mm}$, and $14.5 \mathrm{~mm}$ for E. coli, K. pneumoniae, and $S$. aureus, respectively, $\mathrm{BC} 1$ showed more antibacterial potential than $\mathrm{BC} 2$, which showed corresponding IZD values of $12 \mathrm{~mm}, 10.5 \mathrm{~mm}$, and $11.25 \mathrm{~mm}$. Earlier studies have demonstrated the

Table 1 Antibacterial activity of Bacillus strains

\begin{tabular}{lll}
\hline \multirow{2}{*}{ Pathogen } & \multicolumn{2}{l}{ inhibition zone diameter $(\mathrm{mm})$} \\
\cline { 2 - 3 } & $\mathrm{BC2}$ & $\mathrm{BC1}$ \\
\hline Escherichia coli & $12.00 \pm 0.00$ & $13.00 \pm 0.00$ \\
Klebsiella pneumoniae & $10.50 \pm 0.71$ & $12.00 \pm 2.83$ \\
Staphylococcus aureus & $11.25 \pm 2.11$ & $14.50 \pm 1.34$ \\
\hline Mean + standard deviation $(n=3)$ &
\end{tabular}

antagonistic effect of Bacillus strains against pathogenic bacteria. Manhar et al. (2015) reported the inhibition of K. pneumoniae by B. amyloliquefaciens AMS1. Probiotic Bacillus strain DET6 from food wastes and MKSK-E1, MKSKJ1, and MKSK-M1 from Korean traditional soy sauce inhibited the growth of E. coli (Patel et al. 2009; Lee et al. 2016). In the same vein, Sumathi et al. (2017) reported the antagonistic activity of probiotic B. megaterium from fish gut towards Streptococcus mutans responsible for oral diseases. Pathogen inhibition by bacterial strains has been attributed to a variety of factors including secretion of certain digestive enzymes and inhibitors, competitive exclusion, and cell-to-cell signaling (Hughes and Sperandio 2008). The antimicrobial activity of these Bacillus cultures could inhibit the proliferation of certain pathogens which may accidentally contaminate these fermented foods. This will inadvertently reduce the risk of food infection or intoxication especially during traditional food processing. This may explain the paucity of incidences of food intoxications from consumption of these foods which are often poorly stored due to incessant power failures.

\section{Auto-aggregation}

Figure 1 shows the results of the auto-aggregation test; $\mathrm{BC} 1$ showed higher (53.7\%) auto-aggregation over $3 \mathrm{~h}$ than BC2 (48.69\%). Manhar et al. (2015) reported probiotic Bacillus amyloliquefaciens strains which had the highest degree of auto-aggregation (65.5-75.5\%) observed after $24 \mathrm{~h}$ incubation. The auto-aggregation percentages of the Bacillus cereus strains $\mathrm{BC} 2$ and $\mathrm{BC} 1$ are less than that reported by Lee et al. (2016) for Bacillus strains MKSK -E1, MKSK-M1, and MKSK-J1 isolated from Korean traditional soy sauce. Auto-aggregation is related to the ability of the microbial cells to adhere to the gut epithelial cells (Patel et al. 2009), a key factor in microbial colonization and persistence in the host's gastrointestinal tract.

\section{Antibiotic susceptibility}

Probiotic bacteria are reservoirs of antibiotic resistance genes; therefore, the possibility of their transfer of these genes to pathogenic organisms does not only exist but is a constant concern in dietary use of probiotics (Das et al. 2019), as this may lead to the proliferation of pathogens resistant against commonly used antibiotics. Antibiotic susceptibility test showed that the Bacillus cereus strains, $\mathrm{BC} 1$ and $\mathrm{BC} 2$, were susceptible to streptomycin, erythromycin, ampiclox, gentamycin, and ciprofloxacin, and only resistant to norfloxacin (Table 2). There were differences, however, in the degree of susceptibility to the antibacterial agents as determined by their inhibition zone diameters (IZDs) in $\mathrm{mm}$. Both isolates were highly susceptible to gentamycin with high IZD $(\mathrm{mm})$ of 34.0 and 31.5 for $\mathrm{BC} 1$ and $\mathrm{BC} 2$, respectively, observed. However, while $\mathrm{BC} 1$ was the most susceptible to amplicox $(35.5 \mathrm{~mm})$, and ciprofloxacin $(34.0 \mathrm{~mm}), \mathrm{BC} 2$ was the most 


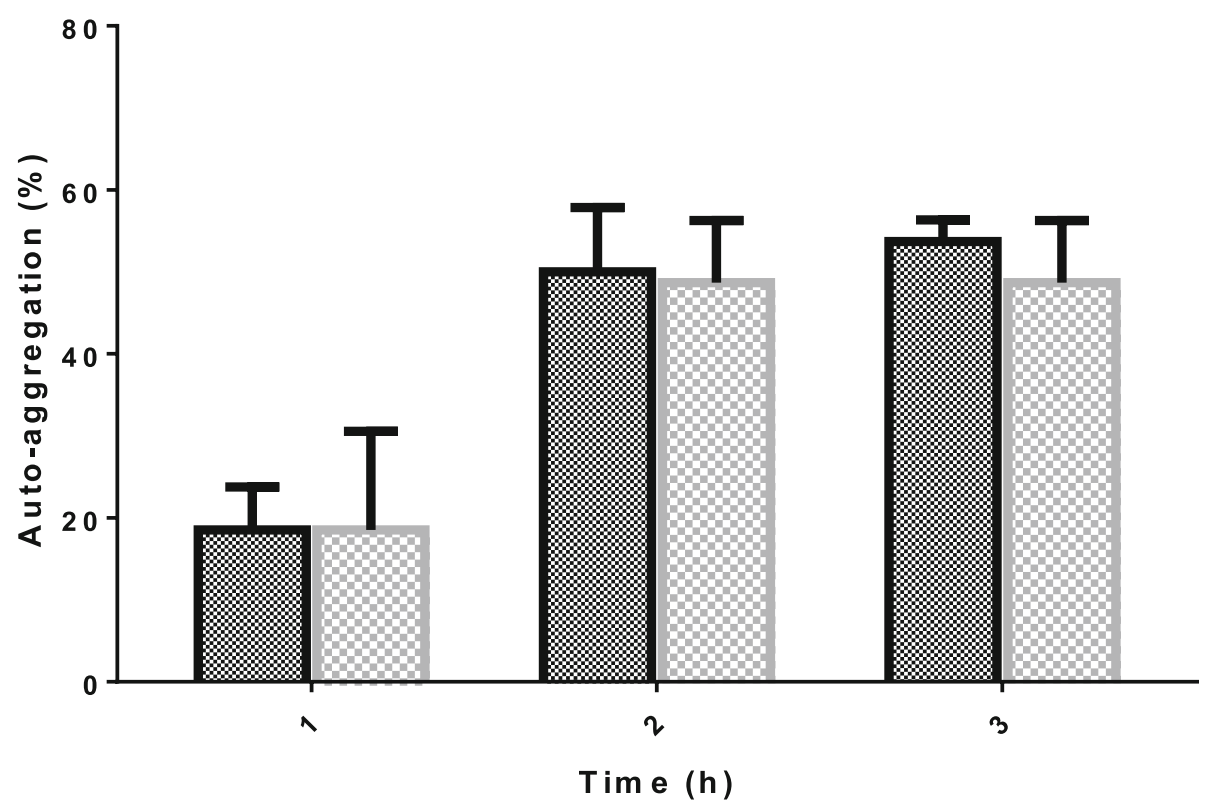

\& B 1

Fig. 1 Auto-aggregation of Bacillus strains

susceptible to ciprofloxacin only $(35.00 \mathrm{~mm})$. Sorokulova et al. (2008) reported that B. licheniformis strain included in a popular east European probiotic was resistant to chloramphenicol and clindamycin. Nithya and Halami (2013) reported a potential probiotic Bacillus coagulans which was resistant to the penicillin group of $\beta$ lactam antibiotics. Bacillus amyloliquefaciens showed sensitivity to all antibiotics tested except penicillin G and ampicillin (Manhar et al. 2015). Hoa et al. (2000) also reported the resistance of probiotic Bacillus against ampicillin and penicillin. Probiotic Bacillus strains, MKSK-E1, MKSK- J1, and MKSK-M1, from Korean traditional soy sauce were susceptible to all antibiotics tested including erythromycin, chloramphenicol, gentamicin,

Table 2 Antibiotic susceptibility of Bacillus isolates

\begin{tabular}{lll}
\hline \multirow{2}{*}{ Antibiotic } & \multicolumn{2}{l}{ inhibition zone diameter $(\mathrm{mm})$} \\
\cline { 2 - 3 } Streptomycin & $21.00 \pm 1.41$ & $\mathrm{BC2}$ \\
Erythromycin & $16.00 \pm 1.41$ & $21.50 \pm 0.71$ \\
Ampiclox & $35.50 \pm 2.12$ & $20.00 \pm 0.00$ \\
Rifampicin & $17.00 \pm 1.41$ & $20.00 \pm 1.41$ \\
Norfloxacin & $\mathrm{Nil}$ & $18.50 \pm 2.12$ \\
Gentamicin & $34.00 \pm 1.41$ & $\mathrm{Nil}$ \\
Amoxil & $20.50 \pm 2.12$ & $31.50 \pm 2.12$ \\
Ciprofloxacin & $26.00 \pm 5.66$ & $20.00 \pm 1.41$ \\
\hline
\end{tabular}

Mean \pm standard deviation $(n=3)$ and cephalexin (Lee et al. 2016). The resistance of our test strains to norfloxacin was not very surprising since Frimodt-Moller et al. (1983) earlier reported that norfloxacin was poorly active against Gram-positive bacteria and inactive against anaerobes. Their susceptibility to a wide range of antibiotics suggests that these Bacillus strains might not carry antibiotic resistant genes which can be transferred to pathogenic microorganisms, subject to further detailed investigations.

\section{Acid and bile salt tolerance}

Acid and bile stability are important parameters and basis for the selection of a probiotic strain; acid resistance is an indication of the potential of the strain to survive the gastric and duodenal juices (Jena et al. 2013). To evaluate the resistance of the Bacillus strains to acidic environment, the strains were cultivated at $\mathrm{pH} 2.5$ for varying hours (Fig. 2). Bacillus cereus strain BC1 maintained over $150 \%$ viability after 1 -h incubation and over $100 \%$ viability after $3 \mathrm{~h}$. BC2 was not as acid stable as $\mathrm{BC} 1$ over the 3-h exposure to the acidic environment. The increase in viability, rather than decline, demonstrated by the organisms in the initial hour of incubation shows that it takes longer exposure for an acid-stressed environment to affect their growth. $\mathrm{BC} 1$ experienced a decline in viability after 2 hours of exposure; subsequent increase in viability at $3 \mathrm{~h}$ implies the strain's ability to favorably readjust the acid-stressed environment and resume growth. This could be by a combination of 


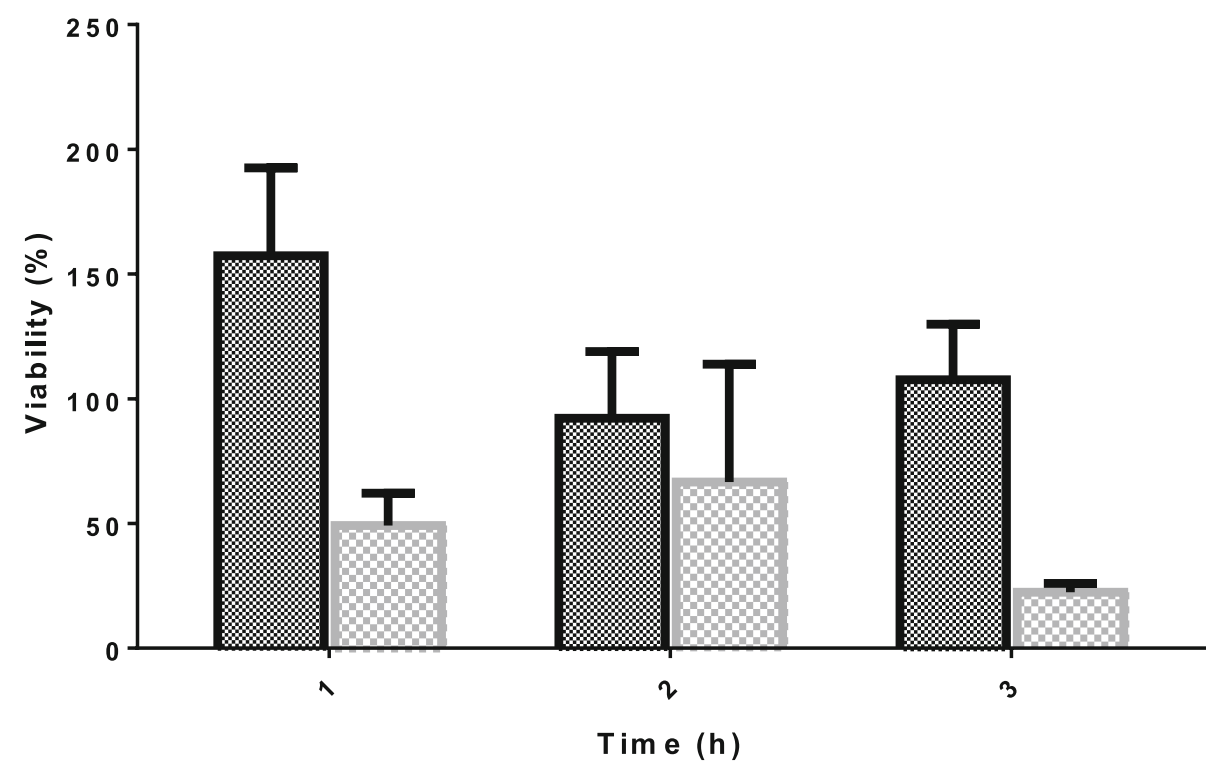

BC 1

Fig. 2 Acid tolerance of Bacillus strains

genetic and physiological mechanisms, common with acidophilic microorganisms. Elsewhere, after exposure to $0.1 \%$ pepsin solution ( $\mathrm{pH} 2.0$ ) for $3 \mathrm{~h}$, probiotic Bacillus strains, MKSK-E1, MKSK-J1, and MKSK-M1, showed relative survival ratios of $93.1 \%, 91.9 \%$, and 96.0\% (Lee et al. 2016).

Bile tolerance is also important for the survival of the probiotic strain in the small bowel. Bacteria growth is inhibited by bile which enters through the duodenal

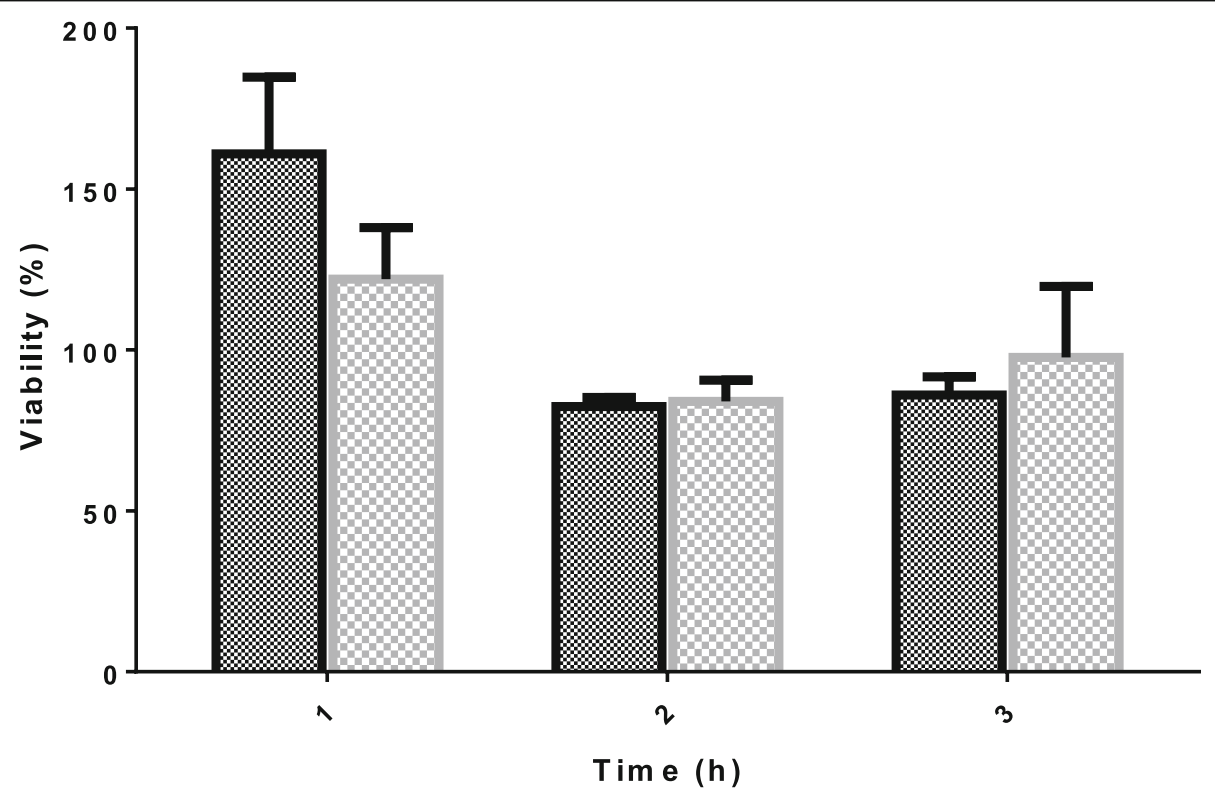

BC 1

B B 2

Fig. 3 Bile salt tolerance of Bacillus strains 
section of the small intestine; this is possible as the bacteria cell membrane is made up of lipids and fatty acids which are sensitive to bile salts. To determine the ability of these strains to survive the intestinal bile, bile tolerance studies were carried out, and results are shown in Fig. 3. BC1 was highly bile tolerant, maintaining above $150 \%$ viability after $1 \mathrm{~h}$ incubation in MRS broth containing $0.4 \%$ bile salt and above $85.0 \%$ after $3 \mathrm{~h}$. BC2 also showed above $100 \%$ viability (122.0 \%) after incubation at $1 \mathrm{~h}$; after $2 \mathrm{~h}$ and $3 \mathrm{~h}$ incubation, the strain maintained $83.0 \%$ and $97.7 \%$ viability, respectively. Kavitha et al. (2018) reported that Bacillus strain FC6 retained $91.62 \%$ viability, $3 \mathrm{~h}$ after exposure to $1 \%$ bile salt. Our findings further agree with the reports of Jini et al. (2011) and Giri and SukumaranV (2012) that probiotic strains are able to survive a range of bile concentrations. Our current result is an indication that these organisms when consumed with the fermented food has the potential to survive the acid- and bile-rich environments, a pre-requisite necessary to reach and survive in the intestinal gut in order to confer its benefits to the host.

\section{Cell hydrophobicity}

Hydrophobicity is an important feature which aids the attachment of probiotic microorganisms to the intestinal epithelium (Lee et al. 2013). Probiotic microorganisms, through their adhesion capability, can prevent pathogen access by steric interactions or specific blockage of cell receptors (Otero et al. 2004). The cell surface hydrophobicity of the Bacillus cereus strains was evaluated by determining the rate of bacteria adhesion to ethyl acetate and chloroform as shown in Fig. 4. For ethyl acetate, $\mathrm{BC} 1$ had lower surface hydrophobicity $(52.8 \%)$ than $\mathrm{BC} 2(58.5 \%)$. However, $\mathrm{BC} 1$ had higher adhesion to chloroform (70.54\%) compared to $49.96 \%$ for $\mathrm{BC} 2$. The Bacillus strains from "daddawa" showed very high hydrophobicity when compared to results obtained from similar studies. Hydrophobicity of the isolates in ethyl acetate was remarkably higher than that of probiotic $\mathrm{Ba}$ cillus spp. DET9, JHT3, and DET6 from food waste with values in the range of $6-12 \%$ (Lee et al. 2013) and MKSK-J1, MKSK-E1, and MKSK-M1 from Korean traditional soy sauce with values less than 35\% (Lee et al. 2016). However, percentage hydrophobicity in chloroform for the Bacillus strains is comparable with results obtained by Kavitha et al. (2018) for Bacillus strains FC6 (65.7 \%) and FS1 (45.08 \%). Cell surface hydrophobicity is reported to increase the propensity of microbial cells to adhere to surfaces; adhesion is the primary stage in microbial colonization, making the cell surface hydrophobicity a crucial property in cell attachment to surfaces (Krasowska and Sigler 2014). Auto-aggregation ability and cell surface hydrophobicity are directly correlated, and according to Manhar et al. (2015),

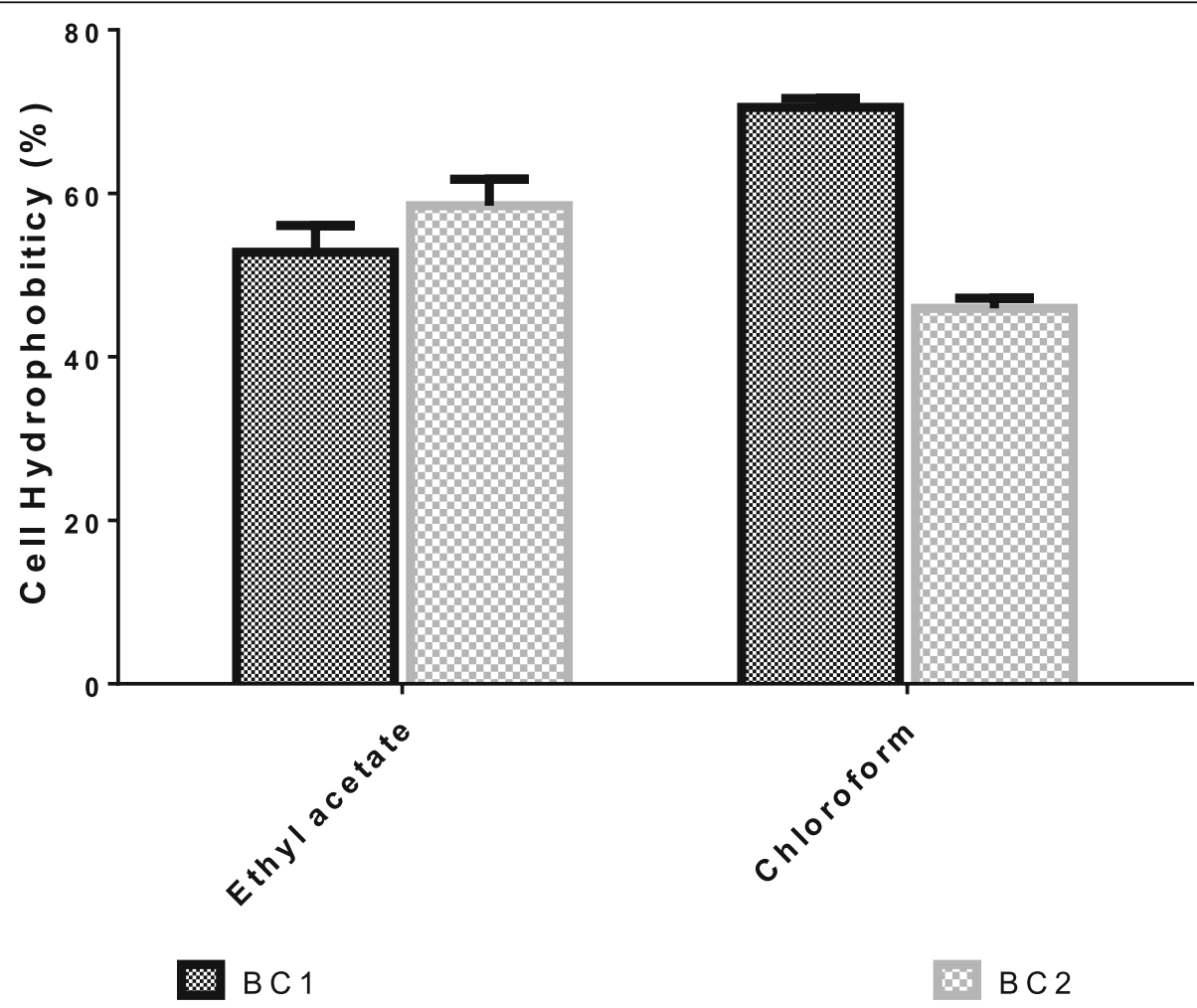

Fig. 4 Cell hydrophobicity of Bacillus strains 
hydrophobicity could be one of the factors that determine the ability of culture to auto-aggregate.

\section{Sodium chloride tolerance}

The Bacillus cereus strains grew well under high salt concentrations as can be seen in Fig. 5. At 10\% salt concentration isolates, $\mathrm{BC} 1$ and $\mathrm{BC} 2$ retained $64.47 \%$ and $74.4 \%$ viability, respectively, after $24 \mathrm{~h}$ incubation. When salt concentration was increased to $15 \%, 12.4 \%$ decrease in viability of $\mathrm{BC} 1$ was observed while $\mathrm{BC} 2$ had $5 \%$ loss in viability, showing that $\mathrm{BC} 2$ was more halotolerant than its counterpart. Pundir et al. (2013) reported tolerance of lactic acid bacteria isolates to $1-6.5 \% \mathrm{NaCl}$ concentration. Also, Lactobacillus spp. isolated from yoghurts tolerated 1-9\% $\mathrm{NaCl}$ (Hoque et al. 2010). Saline stress during microbial growth cause a loss of turgor pressure and water efflux; this adversely affects the cell physiology, enzyme synthesis and activity, water activity, and cell metabolism including carbohydrate, amino acid and fatty acid biosynthesis, and energy generation (Hoffman et al. 2013; Schroeter et al. 2013). Ability to grow well in this stress environment is an indication that it is able to circumvent the adverse effects of salt stress, achieved through proline synthesis, leading to the enhanced expression of genes for the synthesis of exopolysaccharide and capsules.

\section{Amylase and protease production}

Results obtained showed that both Bacillus cereus strains were capable of producing protease but not able to produce amylase. For a probiotic strain to effectively function as a food fermenter, the synthesis of hydrolytic enzymes such as amylase and protease are required to break down the complex food polymers in order to generate simpler compounds such as peptides, amino acids, reducing sugars, and oligosaccharides which will be further converted through other biological reactions to organic acids and other flavor-impacting and health benefiting compounds (Jeon et al. 2017).

Protease helps in improved protein digestion. It is also involved in defense against pathogens through the cleaving of their receptor sites in intestinal epithelial cells (Patel et al. 2009). Bacillus species produce proteases (example, subtilisin) which help digestion and reduce allergenicity. According to Patel et al. (2009), the ability to produce protease could have been the reason why probiotic strain DET6 from food waste showed the best antimicrobial activity of all the isolates they studied. However, this was not observed in the current study. Amylase production is an extra benefit of probiotics given their ability to improve the digestion of starch-rich foods in humans and animals to simpler sugars and oligosaccharides, necessary for generating energy molecules for the microbes. The hydrolytic by-products of these enzymes also engage in biological and chemical reactions to produce flavor compounds which give the fermented food its characteristic properties.

\section{Hemolysis}

Both strains showed no hemolysis on sheep blood agar. This shows that the Bacillus strains as potential

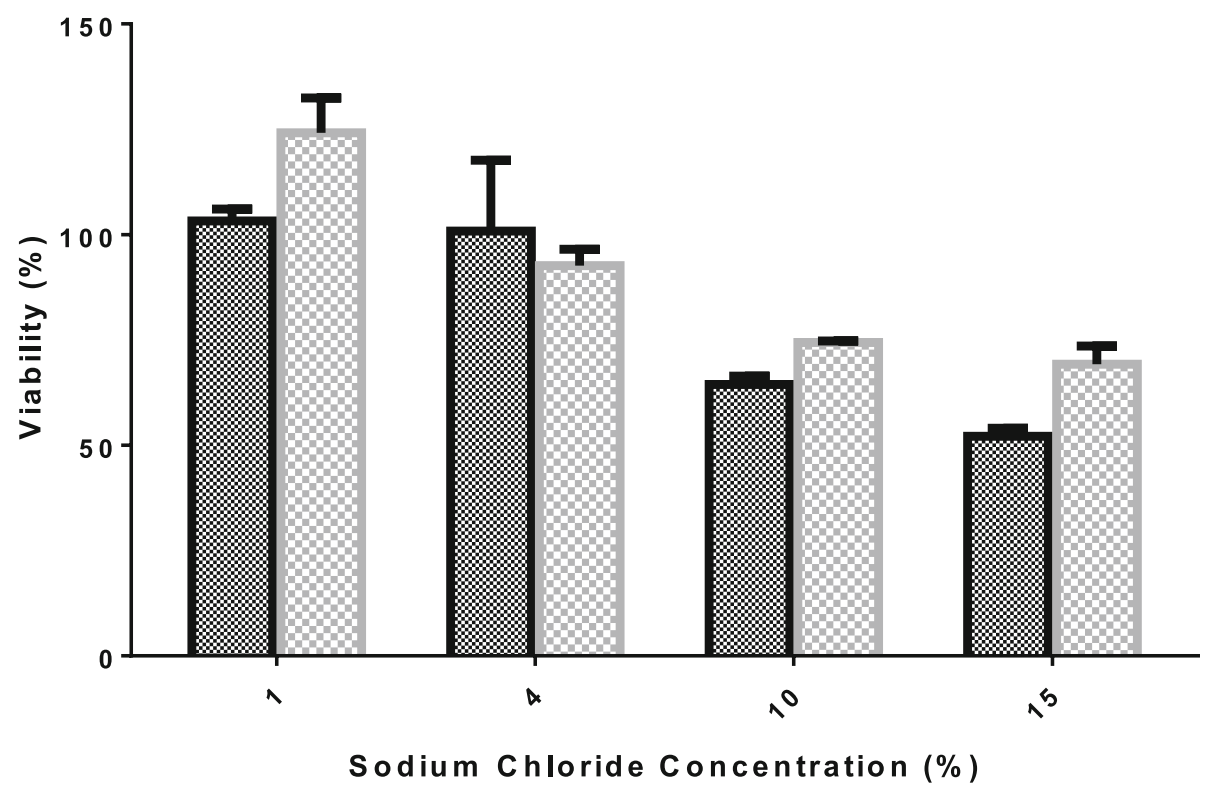

B $\mathrm{B} 1$

B C 2

Fig. 5 Sodium chloride tolerance of Bacillus Isolates 
probiotics satisfy one critical safety parameter. On sheep blood agar, Bacillus probiotic strains were reported to be non-hemolytic by Sorokulova et al. (2008). Also, probiotic Bacillus strains MKSK-M1, MKSK-E1, and MKSK-J1 showed no hemolysis on sheep blood agar (Lee et al. 2016). Inability of the Bacillus strains to lyse blood cells of the host once ingested is an added advantage required for a probiotic strain.

\section{Phenol tolerance}

After $24 \mathrm{~h}$, both strains showed high viability in MRS broth containing $0.2 \%$ phenol (Fig. 6). Strain BC1 was more viable $(245.20 \%)$ than $\mathrm{BC} 2(152.03 \%)$. In the broth containing $0.5 \%$ phenol, the strains also demonstrated high viability after $24 \mathrm{~h}$ of incubation. As can be seen from Fig. 6, viability percentages $190.86 \%$ and $160.78 \%$ were recorded for strains $\mathrm{BC} 2$ and $\mathrm{BC} 1$, respectively. It can therefore be said that the two tested bacterial strains are tolerant to both concentrations of phenol with relatively lower stability observed in higher phenol concentration $(0.5 \%)$. Phenols are toxic metabolites which are released during digestion, by endogenous proteins and some aromatic amino acids. Therefore, a potential probiotic strain should tolerate the limited amounts of phenols in the gastrointestinal tract (Susković et al. 1997). In a similar vein, potential probiotic Lactobacillus species investigated by Tallapragada et al. (2018) were tolerant to $0.2 \%$ and $0.5 \%$ phenol.

\section{Selection of strain for in vivo testing}

Statistical analysis indicated that both Bacillus strains possess comparable probiotic attributes. However, BC1 was chosen for in vivo anti-inflammatory testing due to its higher antibacterial activity compared to $\mathrm{BC} 2$.

\section{In vivo anti-inflammatory activity of spores of Bacillus BC1}

The paws of category one rats (comprised of four groups) were injected with carrageenan $30 \mathrm{~min}$ after administering oral treatments to them. The thickness of the resulting edema was measured and recorded at various intervals, immediately after injection $(0 \mathrm{~h}), 4 \mathrm{~h}$, and $24 \mathrm{~h}$. The progression of the paw thickness for rats in groups 2 or $200 \mathrm{~S}$ (200 $\mu \mathrm{l}$ spores) and group 3 or $500 \mathrm{~S}$ (500 $\mu \mathrm{l}$ spores) were compared to the progression observed in the control experiments, group 1 or $\mathrm{NegC}$ (Negative control) and group 4 or PosC $(150 \mathrm{mg} / \mathrm{kg}$ diclofenac sodium) in Fig. 7. From our observations, the mean paw thickness of the NegC rats almost doubled immediately after the injection (from $0.373 \mathrm{~cm}$ before injection to $0.713 \mathrm{~cm}$ ) and slightly increased to $0.718 \mathrm{~cm}$ after $4 \mathrm{~h}$. This was followed by a decrease to $0.568 \mathrm{~cm}$ after $24 \mathrm{~h}$, while for PosC rats, paw thickness was only observed to increase from $0.410 \mathrm{~cm}$ to $0.673 \mathrm{~cm}$, immediately after injection $(0 \mathrm{~h})$. Afterwards, there was a progressive drop in thickness to $0.618 \mathrm{~cm}$ and to $0.440 \mathrm{~cm}$ after $4 \mathrm{~h}$ and $24 \mathrm{~h}$, respectively. From an initial 0.383

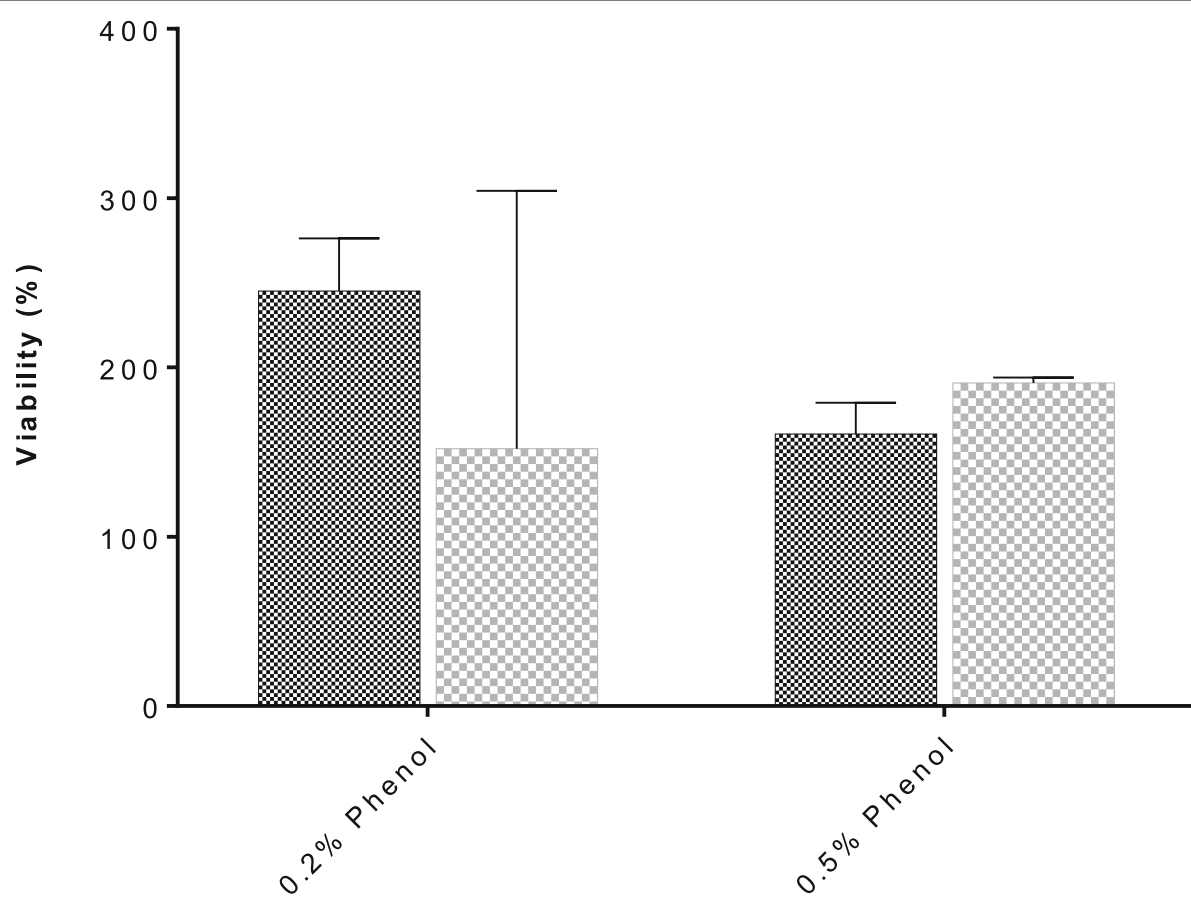

B C 2

Fig. 6 Phenol tolerance of Bacillus Isolates 
$\mathrm{cm}$, the paw thickness of the animals in group 2 or $200 \mathrm{~S}$ (200 $\mu \mathrm{l}$ spores) increased to $0.650 \mathrm{~cm}$ and to $0.675 \mathrm{~cm}$ at $0 \mathrm{~h}$ and $4 \mathrm{~h}$ respectively, then dropped to $0.473 \mathrm{~cm}$ at 24 h. From $0.380 \mathrm{~cm}$ before injection, the paw thickness of $500 \mathrm{~S}$ rats progressively increased to $0.598 \mathrm{~cm}$ at $0 \mathrm{~h}$ and to $0.675 \mathrm{~cm}$ at $4 \mathrm{~h}$ before dropping to $0.500 \mathrm{~cm}$ at $24 \mathrm{~h}$. Figure 8 shows edema inhibition (\%) of the various treatments for all the groups in category one after $24 \mathrm{~h}$, as evaluated from Fig. 7. When compared to $89.150 \%$ inhibition obtained for PosC (treated with the control drug), $200 \mathrm{~S}$ and $500 \mathrm{~S}$ animals showed $76.335 \%$ and $68.130 \%$ edema inhibition, respectively. To also monitor inflammation inhibition by the various treatments, motility scores (on a scale of 1 to 5) were recorded in Fig. 9. All the rats showed some motility $24 \mathrm{~h}$ after injection. NegC, 200S, 500S, and PosC rats had motility ratings of 1.250 , $3.00,3.250$, and 2.50 , respectively.

Carrageenan-induced inflammation is one of the most appropriate methods of evaluating the effect of antiinflammatory agents in animal models (Du et al. 2018). The edema produced by carrageenan injection is characterized by swelling and increase in paw thickness (Cuzzocrea et al. 1998). Commonly used non-steroidal antiinflammatory agents like aspirin and indomethacin are associated with a lot of adverse effects (Hatt et al. 2018). This has led to increased interest in natural substances with anti-inflammation potential. Just like other probiotic organisms, probiotic Bacillus is known to confer a number of health benefits on the host including the alleviation of inflammation (Chen et al. 2010; Schultz et al. 2017). In this study, spores of Bacillus strain $\mathrm{BC} 1$, instead of the commonly used vegetative cells, were tested for antiinflammatory potential. The high stability of spores when used as probiotic formulations informed this choice. There are questions over whether spores of Bacillus can become active in the gastrointestinal tract for probiotic benefit (Spinosa et al. 2000). Schultz et al. (2017) are of the opinion that non germinated spores could possibly provide immunologic benefit to the host and argues that the spores are likely to germinate and grow in order to become fully active. Spores are able to survive transit through the acidic stomach, after which they can germinate, grow, proliferate, and resporulate before being excreted in the faeces (Le Duc et al. 2004; Hong et al. 2009). It was observed that spores of Bacillus $\mathrm{BC} 1$ being investigated for probiotic potential produced significant $(p<$ 0.05) edema inhibition. Probiotics increase the production of short-chain fatty acids (SCFAs) such as butyrate, acetate, and propionate in the gastrointestinal tract (GIT) of humans: compounds known to stimulate antiinflammatory effects (Kerry et al. 2018). This is one mechanism by which probiotics cells and spores inhibit inflammation in the treated host.

Since probiotic strains are expected to confer health benefits on the host, this quality makes the strain an excellent probiotic candidate. It was strangely observed that $200 \mu \mathrm{l}$ spores produced better inflammation inhibition than $500 \mu \mathrm{l}$. It is possible that at a relatively high concentration $(500 \mu \mathrm{l})$, spore germination ratio is reduced, resulting in lower anti-inflammatory effect

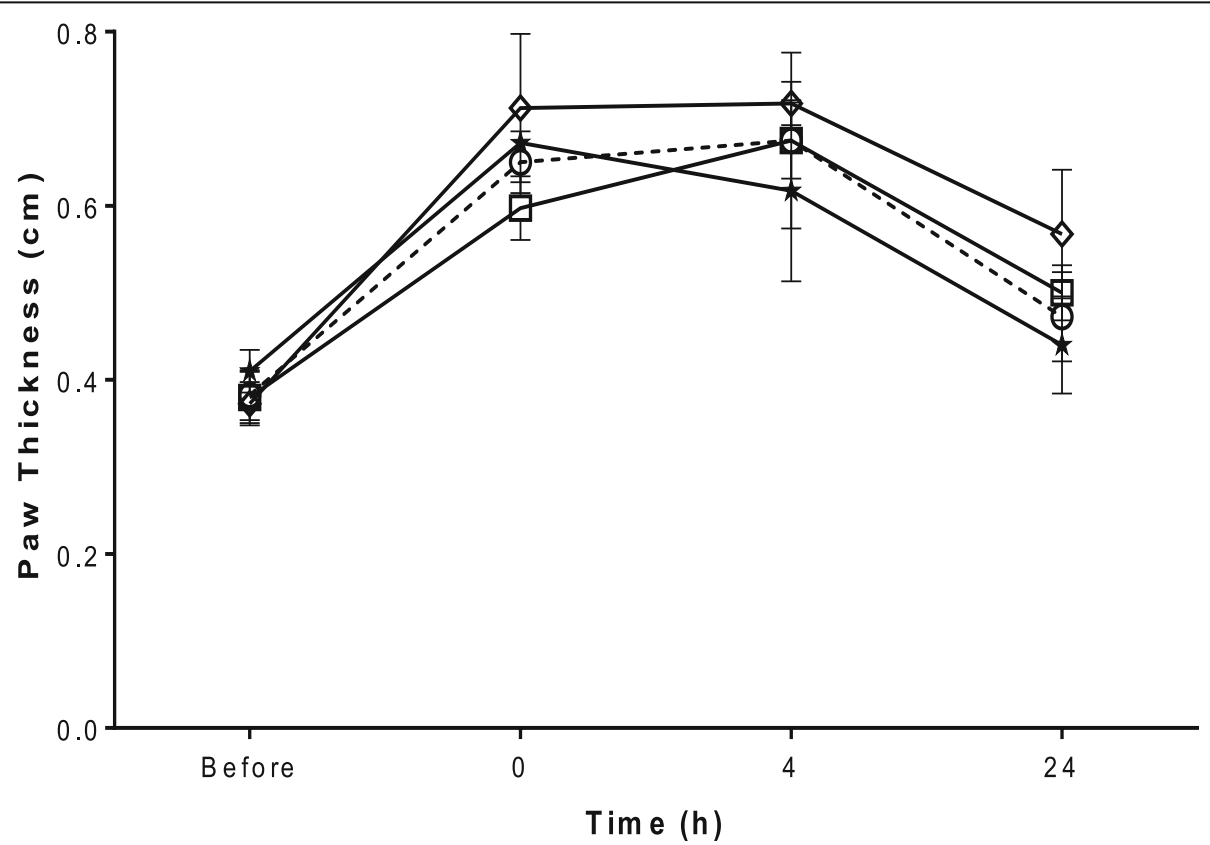

Fig. 7 Changes in paw thickness (cm) of Wistar rats after administering the Bacillus spores. NegC (diamond), $500 \mu$ l distilled water; 2005 (circle), $200 \mu \mathrm{l}$ Spores; $500 \mathrm{~S}$ (square), $500 \mu \mathrm{l}$ Spores; PosC (star), diclofenac sodium (150 mg/kg) 


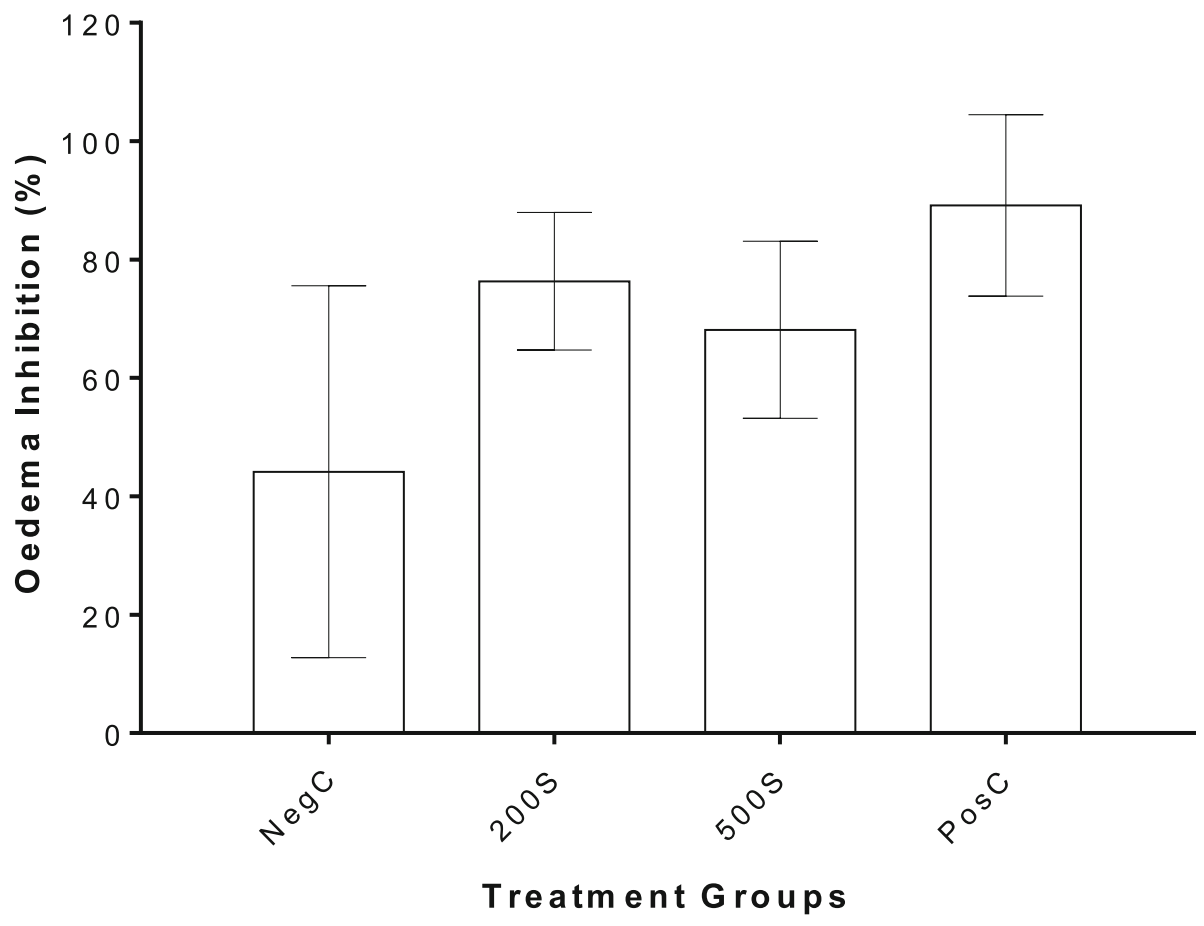

Fig. 8 Edema inhibition after administering the Bacillus spores. NegC, $500 \mu$ l Distilled water; 200S, $200 \mu l$ spores; $500 S, 500 \mu l$ Spores; PosC, diclofenac sodium $(150 \mathrm{mg} / \mathrm{kg})$

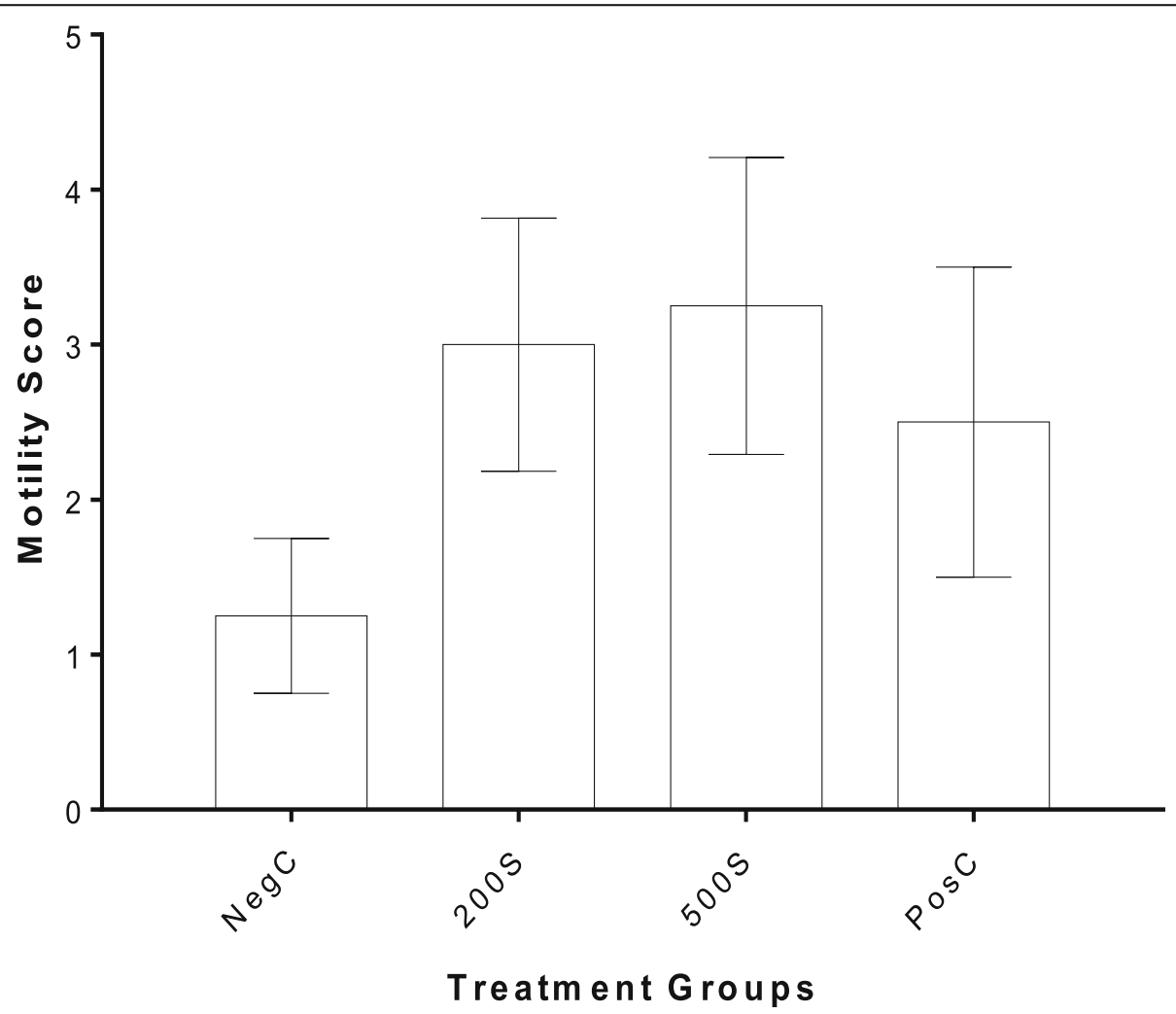

Fig. 9 Effect of the Bacillus spores on the mobility of rats after induction of inflammation. NegC, $500 \mu$ l distilled water; 200S, 200 $\mu$ l spores; 500S, $500 \mu \mathrm{l}$ spores; PosC, diclofenac sodium $(150 \mathrm{mg} / \mathrm{kg})$ 
compared with $200 \mu \mathrm{l}$ spore concentration. Elsewhere, spores of potential probiotic strain B. subtilis PB6 decreased the serum levels of IL-6 and SAA, important systemic markers of inflammation in mice (Foligné et al. 2012).

As earlier stated, these organisms were isolated based on their ability to produce "daddawa" of accepted qualities and properties. Considering the above findings, it is obvious that the Bacillus cereus strains in this study possess probiotic qualities. This has a number of implications; fermented African foods in this case "daddawa" produced from alkaline fermentation harbor probiotic Bacillus strains, and these strains are expected to play a large role in conferring the health benefits attributed to consuming fermented foods. It is worthy to note at this point that B. cereus strains abound in "daddawa" and its consumption in the fresh or cooked form are regarded as safe, as there is no report of associated intestinal disorder (2010). It is well documented that fermented maize grain popularly known as "ogi/akamu" in Nigeria possesses anti-diarrhoeal properties, though no research has been done to determine which particular organisms are responsible for this property. Having this in mind, the consumption of these indigenous fermented foods should be encouraged and the controlled production given more attention. Fermented Africa locust bean seed is consumed in many Africa countries as seasoning agents for many soups and stews. In some parts of Eastern Nigeria, it is consumed right after fermentation (without further cooking) as seasoning agents and protein supplements in foods such as wet cassava flakes popularly known as "African salad." The benefits of fermenting "daddawa" include detoxification of the seed, removal of anti-nutrients, increasing the availability of plant nutrients as well as essential vitamins, improved taste, food flavor, and consistency in product quality. However, using probiotic cultures during these fermentations will equally ensure that these foods serve as a vehicle for probiotic therapy ensuring multiple health benefits to the host. The Bacillus strains have indicated promising probiotic qualities and with further research may be invaluable as probiotic strains for animals and probably humans.

\section{Conclusion}

The Bacillus cereus strains isolated from traditional fermented "daddawa" possess probiotic attributes. Considering that daddawa/iru is popularly consumed as food condiment by various tribes in West Africa, either in cooked or raw form, it is important that the fermenting cultures used should not only improve its organoleptic quality but also afford a wide array of health benefits, especially considering the poor socio-economic conditions of majority of the consumers. Probiotic strains not only have the potential to confer a lot of health benefits when consumed but also produce antimicrobial substances capable of inhibiting growth of pathogenic strains. The use of these Bacillus cultures for "daddawa" production will therefore enhance product taste and quality. Also, this implies that "daddawa/iru" could be used as vehicle for probiotic delivery. The Bacillus strains studied have the potential for application in both human and animal food/feed formulations though this is subject to further examination.

\section{Acknowledgements \\ Not applicable}

\section{Authors' contributions}

TNT and CJU designed the experiment. AC, UOC, and Ol carried out the laboratory experiments, CJU assisted in the laboratory experiments and analyzed the data and participated in writing the manuscript, TNT and COO assisted in data analysis and wrote the manuscript. All authors read and approved the final manuscript.

Funding

None

Availability of data and materials

Data sharing is not applicable to this article as no datasets were generated or analyzed during the current study.

Ethics approval and consent to participate

All experimental protocols were approved by the Ethics Committee, Faculty of Biological Sciences, University of Nigeria.

Consent for publication

Not applicable

\section{Competing interests}

The authors declare that they have no competing interests.

Received: 12 January 2020 Accepted: 31 March 2020

Published online: 30 April 2020

\section{References}

Anand C, Gordon R, Shaw H, Fonseca K, Olsen M (2000) Pig and goat blood as substitutes for sheep blood in blood-supplemented agar media. J Clin Microbiol 38:591-594 https://www.ncbi.nlm.nih.gov/pmc/articles/PMC86154/ Angmo K, Kumari A, Bhalla TC (2016) Probiotic characterization of lactic acid bacteria isolated from fermented foods and beverage of Ladakh. LWT Food Sci Technol 66:428-435 https://doi.org/10.1016/j.lwt.2015.10.057

Bader J, Skelac L, Wewetzer S, Senz M, Popović MA, Bajpai R (2012) Effect of partial pressure of $\mathrm{CO}_{2}$ on the production of thermostable a-amylase and neutral protease by Bacillus caldolyticus. Appl Biochem Microbiol 48:182-187 https://doi.org/10.1134/S0003683812020032

Bakirtzi K, Law IK, Xue X, Ilopoulos D, Shah YM, Pothoulakis C (2016) Neurotensin promotes the development of colitis and intestinal angiogenesis via Hif-1amiR-210 signaling. J Immunol 196:4311-4321 https://doi.org/10.4049/ jimmunol.1501443

Bernfeld P (1955) Amylase $a$ and $\beta$. Method Enzymol 1:149-158 https://doi.org/ 10.1016/0076-6879(55)01021-5

Burgain J, Gaiani C, Linder M, Scher J (2011) Encapsulation of probiotic living cells: from laboratory scale to industrial application. J Food Eng 104:467-483 https://doi.org/10.1016/j.ffoodeng.2010.12.031

Chen C-C, Kong M-S, Lai M-W, Chao H-C et al (2010) Probiotics have clinical, microbiologic, and immunologic efficacy in acute infectious diarrhea. Pediatr Infect Dis J 29:135-138 https://doi.org/10.1097/NF.0b013e3181b530bf

Chugh B, Kamal-Eldin A (2020) Bioactive compounds produced by probiotics in food products. Curr Opin Food Sc In press. https://doi.org/10.1016/j.cofs.2020. 02.003

Cutting SM (2011) Bacillus probiotics. Food Microbiol 28:214-220 https://doi.org/ 10.1016/j.fm.2010.03.007 
Cuzzocrea S, Zingarelli B, Hake P, Salzman AL, Szabo C (1998) Antiinflammatory effects of mercaptoethylguanidine, a combined inhibitor of nitric oxide synthase and peroxynitrite scavenger, in carrageenan-induced models of inflammation. Free Rad Biol Med 24:450-459 https://doi.org/10.1016/S08915849(97)00280-3

Das DJ, Shankar A, Johnson JB, Thomas S (2019) Critical insights into antibiotic resistance transferability in probiotic Lactobacillus. Nutrition 13:69 https:/doi.org/10.1016/j.nut. 2019.110567

Du B, Zhu F, Xu B (2018) An insight into the anti-inflammatory properties of edible and medicinal mushrooms. J Funct Foods 47:334-342 https://doi.org/10.1016/j.jff.2018.06. 003

Ezeokoli OT, Adeleke RA, Bezuidenhout CC (2018) Core bacterial community of soy-daddawa: Insights from high-throughput DNA metabarcoding. LWT-Food Sci Technol 97:61-66 https://doi.org/10.1016/j.lwt.2018.06.039

FAO/WHO (2002) Joint FAO/WHO (Food and Agriculture Organization/ World Health Organization) working group report on drafting guidelines for the evaluation of probiotics in food, London; Ontario https://www.who.int/ foodsafety/fs_management/en/probiotic_guidelines.pdf

Foligné B, Peys E, Vandenkerckhove J, Van Hemel J, Dewulf J et al (2012) Spores from two distinct colony types of the strain Bacillus subtilis PB6 substantiate anti-inflammatory probiotic effects in mice. Clin Nutr 31:987-994 https://doi. org/10.1016/j.clnu.2012.05.016

Franz CM, Huch M, Mathara JM, Abriouel H et al (2014) African fermented foods and probiotics. Int J Food Microbiol 190:84-96 https://doi.org/10.1016/j. ijfoodmicro.2014.08.033

Frimodt-Moller PC, Jensen EMK, Madsen P (1983) Antibacterial activity of norfloxacin in the gastrointestinal tracts of rats. Antimicrob Agents Chemo 24:560-563 https://doi.org/10.1128/aac.24.4.560

Gashtasbi F, Ahmadian G, Noghabi KA (2014) New insights into the effectiveness of alpha-amylase enzyme presentation on the Bacillus subtilis spore surface by adsorption and covalent immobilization. Enz Microb Technol 64-65:17-23 https://doi.org/10.1016/j.enzmictec.2014.05.006

Giri S, SukumaranV DNK (2012) Characteristics of bacterial isolates from the gut of freshwater fish, Labeo rohita that may be useful as potential probiotic bacteria. Prob Antimicrob Proteins 4:238-242 https://doi.org/10.1007/s12602-012-9119-6

Hatt KM, Vijapura A, Maitin IB, Cruz E (2018) Safety considerations in prescription of NSAIDs for Muscoskeletal pain: a narrative review. PM R. 10:1404-1411 https://doi.org/10.1016/j.pmrj.2018.06.011

Hill C, Guarner F, Reid G, Gibson GR, Merenstein DJ, Pot B et al (2014) Expert consensus document: The International Scientific Association for Probiotics and Prebiotics consensus statement on the scope and appropriate use of the term probiotic. Nat Rev Gastroenterol Hepatol 11:506-514 https://doi. org/10.1038/nrgastro.2014.66

Hoa NT, Baccigalupi L, Huxham A, Smertenko A, Van PH et al (2000) Characterization of Bacillus species used for oral bacteriotherapy and bacterioprophylaxis of gastrointestinal disorders. Appl Environ Microbiol 66: 5241-5247 https://doi.org/10.1128/aem.66.12.5241-5247.2000

Hoffman T, Wensing A, Brosius M, Steil L, Volker U, Bremer E (2013) Osmotic control of opuA expression in Bacillus subtilis and its modulation in response to intracellular glycine betaine and proline pools. J Bacteriol 95:510-522 https://doi.org/10.1128/JB.01505-12

Hong HA, Khaneja R, Tam NM, Cazzato A et al (2009) Bacillus subtilis isolated from the human gastrointestinal tract. Res Microbiol 160:134-143 https://doi.org/ 10.1016/j.resmic.2008.11.002

Hoque MZ, Akter F, Hossain KM, Rahman MS, Billah MM, Islam KM (2010) Isolation, identification and analysis of probiotic properties of Lactobacillus sp. from selective regional yoghurts. World J Dairy Food Sci 5:39-46 https:// pdfs.semanticscholar.org/7b21/e95f9af119829321cac4c001989612ff675d.pdf

Horosheva TV, Vodyanoy V, Sorokulova I (2014) Efficacy of Bacillus probiotics in prevention of antibiotic-associated diarrhoea: a randomized, double-blind, placebo-controlled clinical trial. JMM Case Rep 1(3) https://doi.org/10.1099/jmmcr.0.004036

Hughes DT, Sperandio V (2008) Inter-kingdom signaling: communication between bacteria and their hosts. Nat Rev Microbiol 6:111-120 https://doi. org/10.1038/nrmicro1836

Jena PK, Trivedi D, Thakore K, Chaudhary H, Giri SS, Seshadri S (2013) Isolation and characterization of probiotic properties of Lactobacilli isolated from rat fecal microbiota. Microbiol Immunol 57:407-416 https://doi.org/10.1111/ 1348-0421.12054

Jeon H, Lee N, Yang S, Kim W, Pak H (2017) Probiotic characterization of Bacillus subtilis P223 isolated from Kimchi. Food Sc Biotechnol 26:1641-1648 https:// doi.org/10.1007/s10068-017-0148-5
Jiang Y, Zhou S, Chu W (2019) The effects of dietary Bacillus cereus QSI-1 on skin mucus proteins profile and immune response in Crucian Carp (Carassius auratus gibelio). Fish Shell Immunol 89:319-325 https://doi.org/10.1016/j.fsi. 2019.04.014

Jini R, Swapna HC, Rai AK et al (2011) Isolation and characterization of potential lactic acid bacteria (LAB) from freshwater fish processing wastes for application in fermentative utilization of fish processing waste. Braz J Microbiol 42:15161525 https://www.ncbi.nlm.nih.gov/pmc/articles/PMC3768748/

Kavitha M, Raja M, Perumal P (2018) Evaluation of probiotic potential of Bacillus spp. isolated from the digestive tract of freshwater fish Labeo calbasu (Hamilton, 1822). Aqua Rep 11:59-69 https://doi.org/10.1016/j.aqrep.2018.07.001

Kerry RG, Patra JK, Gouda S, Park Y, Shin H, Das G (2018) Benefaction of probiotics for human health: a review. J Food Drug Anal 26:927-939

Krasowska A, Sigler K (2014) How microorganisms use hydrophobicity and what does this mean for human needs? Front Cell Inf Microbiol 4:112 https://doi. org/10.3389/fcimb.2014.00112

Kristensen NB, Bryrup T, Allin KH, Nielsen T, Hansen TH, Pedersen O (2016) Alterations in fecal microbiota composition by probiotic supplementation in healthy adults: a systematic review of randomized controlled trials. Genome Med 8:1-11 https://doi.org/10.1186/s13073-016-0300-5

Kuebutornye FKA, Abarike ED, Lu Y (2019) A review on the application of Bacillus as probiotics in aquaculture. Fish Shellfish Immunol 87:820-828 https://doi. org/10.1016/j.fsi.2019.02.010

Lakshmi SG, Jayanthi N, Saravanan M, Sudha Ratna M (2017) Safety assesment of Bacillus clausii UBBC07, a spore forming probiotic. Toxicol Rep 4:62-71 https://doi.org/10.1016/j.toxrep.2016.12.004

Le Duc H, Hong HA, Barbosa TM, Henriques AO, Cutting SM (2004) Characterization of Bacillus probiotics available for human use characterization of Bacillus probiotics available for human use. Appl Environ Microbiol 70:2161-2171 https://doi.org/10.1128/AEM.70.4.2161-2171.2004

Lee N, Kim S, Choi S, Paik H (2013) Probiotic Bacillus Subtilis KU201 having antifungal and antimicrobial properties isolated from kimchi. Food Sci Biotechnol 22:1-5 https://doi.org/10.1007/s10068-013-0225-3

Lee S, Lee J, Jin Y, Jeong JC et al (2016) Probiotic characteristics of Bacillus strains isolated from Korean traditional soy sauce. LWT - Food Sc Technol 79:518524 https://doi.org/10.1016/j.lwt.2016.08.040

Lefevre M, Racedo S, Denayrolles M, Ripert G et al (2017) Safety assessment of Bacillus subtilis CU1 for use as a probiotic in humans. Regul Toxicol Pharmacol 83:54-65 https://doi.org/10.1016/j.yrtph.2016.11.010

Manhar AK, Saikia D, Bashir Y, Mech RK, Nath D et al (2015) In vitro evaluation of celluloytic Bacillus amyloliquefaciens AMS1 isolated from traditional fermented soybean (Churpi) as an animal probiotic. Res Vet Sc 99:149-156 https://doi.org/10.1016/j.rvsc.2015.01.008

Metlakunta AS, Soman R (2020) Safety evaluation of Bacillus coagulans SNZ 1969 in Wistar rats. Regul Toxicol Pharmacol 110:104538 https:/doi.org/10.1016/j.yrtph.2019.104538

Nithya V, Halami PM (2013) Evaluation of the probiotic characteristics of Bacillus species isolated from different food sources. Ann Microbiol 63:129-137 https://doi.org/10.1007/s13213-012-0453-4

Nwagu TN, Nomeh N, Amadi OC (2015) Production of a thermostable alkaline protease from alkalophilic Kocuria varians grown on various agricultural wastes. Acta Aliment 44:317-325.

Nwagu TN, Orji MU, Nwobodo I, Nwobodo HA (2011) Mixed microbial flora as starter culture for production of Ugba from African oil bean seed. Asian Biol Sc 4:62-69 https://scialert.net/fulltextmobile/?doi=ajbs.2011.62.69

Oguntoyinbo FA, Abiodun IS, Franz CA, Holzapfel WH (2007) In vitro fermentation studies for selection and evaluation of Bacillus strains as starter cultures for the production of okpehe, a traditional African fermented condiment. Int J Food Microbiol 113:208-218 https://doi.org/10.1016/j.ijfoodmicro.2006.07.006

Otero MC, Ocana VS, Macias EN (2004) Bacterial surface characteristics applied to selection of probiotic microorganisms. Methods Mol Biol 268:435-440 https://doi.org/10.1385/1-59259-766-1:435

Patel AK, Ahire JJ, Pawar SP, Chaudhari BL, Chincholkar SB (2009) Comparative accounts of probiotic characteristics of Bacillus strains isolated from food wastes. Food Res Int 42:505-510 https://doi.org/10.1016/j.foodres.2009.01.013

Plaza-Diaz J, Ruiz-Ojeda FJ, Gil-Campos M, Gil A (2019) Mechanisms of action of probiotics. Adv Nutr 10(1):S49-S66 https://doi.org/10.1093/advances/nmy063

Pundir RK, Rana S, Kashyap N, Kaur A (2013) Probiotic potential of lactic acid bacteria isolated from food samples: an in vitro study. J Appl Pharm Sc 00: 85-93 https://doi.org/10.7324/JAPS.2013.30317

Reid G, Gadir AA, Dhir R (2019) Probiotics: reiterating what they are and what they are not. Microbiol. https://doi.org/10.3389/fmicb.2019.00424 
Rokana N, Mallappa RH, Batish VK, Grover S (2016) Interaction between putative probiotic Lactobacillus strains of Indian gut origin and Salmonella: Impact on intestinal barrier function. LWT Food Sc Technol 84:851-860 https:/doi.org/10.1016/J.lwt.2016.08.021

Ryu EH, Chang HC (2013) In vitro study of potentially probiotic lactic acid bacteria strains isolated form kimchi. Ann Microbiol 63:1387-1395 https://doi. org/10.1007/s13213-013-0599-8

Sanders ME, Merenstein DJ, Reid G, Gibson GR, Rastall RA (2019) Probiotics and prebiotics in intestinal health and disease: from biology to the clinic. Nat Rev Gastroenterol Hepatol 16:605-616 https://doi.org/10.1038/s41575-019-0173-3

Sazawal S, Hiremath G, Dhingra U, Malik P et al (2006) Efficacy of probiotic in prevention of acute diarrhea, a metaanalysis of masked, randomized, placebo-controlled trials. Lan Infect Dis 6:374-382 https:/doi.org/10.1016/S1473-3099(06)70495-9

Schroeter R, Hoffmann T, Voigt B, Meyer H, Bleisteiner M et al. (2013) Stress responses of the industrial workhorse Bacillus licheniformis to osmotic challenges. PLoS One 8: e80956. https://doi.org/10.1371/journal.pone.0080956

Schultz M, Burton JP, Chanyi RM (2017) Use of Bacillus in human intestinal probiotic applications. In: Floch MH, Ringel Y, Walker WA (eds) The microbiota in gastrointestinal pathophysiology implications for human health, prebiotics, probiotics and dysbiosis,1 19-123. Academic Press, UK

Singh K, Kallali B, Kumar A, Thaker V (2011) Probiotics: a review. Asian Pac JTrop Biomed 1:287-290

Solanki HK, Shah DA, Maheriya PM, Patel CA (2015) Evaluation of antiinflammatory activity of probiotic on carrageenan-induced paw edema in Wistar rats. Int J Biol Macromol 72:1277-1282 https://doi.org/10.1016/S2221$1691(11) 60174-3$

Son SH, Jeon JL, Yang SJ, Sim MH et al (2018) Probiotic lactic acid bacteria isolated from traditional Korean fermented foods based on $\beta$-glucosidase activity. Food Sc Biotechnol 27:123-129 https://doi.org/10.1007/s10068-017-0212-1

Sorokulova IB, Pinchuk IV, Denayrolles M, Osipova IG et al (2008) The safety of two Bacillus probiotic strains for human use. Digest Dis Sc 53:954-963 https://doi.org/10.1007/s10620-007-9959-1

Spinosa MR, Braccini T, Ricca E, Felice MD et al (2000) On the fate of ingested Bacillus spores. Res Microbiol 151:361-368 https://doi.org/10.1016/s09232508(00)00159-5

Sudjarwo SA (2005) Anti-inflammatory and analgesic effect of bromelain in mice and rats. Universa Medicina 24:155-160 https://pdfs.semanticscholar.org/4a4 c/15ff50ea048cccefc7ffbe287561d3382203.pdf

Suez J, Zmora N, Segal E, Elinav E (2019) The pros, cons, and many unknowns of probiotics. Nat Med 25:716-729 https://doi.org/10.1038/s41591-019-0439-x

Sumathi C, Nandhini A, Padmanaban J (2017) Antagonistic activity of probiotic Bacillus megaterium against Streptococcus mutans. Int J Pharm Bio Sci 8:270274 https://doi.org/10.22376/ijpbs.2017.8.1.p270-274

Sumi CD, Yang B, Yeo I-C, Hahm YT (2015) Antimicrobial peptides of the genus Bacillus: a new era for antibiotics. Can J Microbiol 61:93-103 https:/doi.org/10.1139/cjm-20140613

Susković J, Brkić B, Matošić S, Marić V (1997) Lactobacillus acidophilus M92 as potential probiotic strain. Milchwissenschaft 52:430-445 https://www.bib.irb.hr/4195

Tallapragada P, Rayavarapu B, Rao PP, Ranganath N, Veerabhadrappa P (2018) Screening of potential probiotic lactic acid bacteria and production of amylase and its partial purification. J Genetic Eng Biotechnol 16:357-362 https://doi.org/10.1016/j.jgeb.2018.03.005

Tamang JP, Watanabe K, Holzapfel WH (2016) Review: diversity of microorganisms in global fermented foods and beverages. Front Microbiol 7 : 377 https://doi.org/10.3389/fmicb.2016.00377

Wang D, Liu W, Ren Y, De L et al (2016) Isolation and identification of lactic acid bacteria from traditional dairy products in Baotou and Bayannur of Midwestern Inner Mongolia and q-PCR analysis of predominant species. Kor J Food Sc Anim Resour 36:499-507 https://doi.org/10.5851/kosfa.2016.36.4.499

Zhao Y, Yuan L, Wan J, Sun Z, Wang Y, Sun H (2016) Effects of potential probiotic Bacillus cereus EN25 on growth, immunity and disease resistance of juvenile sea cucumber Apostichopus japonicas. Fish Shell Immunol 49:237-242 https:// doi.org/10.1016/j.fsi.2015.12.035

\section{Publisher's Note}

Springer Nature remains neutral with regard to jurisdictional claims in published maps and institutional affiliations.

\section{Ready to submit your research? Choose BMC and benefit from}

- fast, convenient online submission

- thorough peer review by experienced researchers in your field

- rapid publication on acceptance

- support for research data, including large and complex data types

- gold Open Access which fosters wider collaboration and increased citations

- maximum visibility for your research: over $100 \mathrm{M}$ website views per year

At BMC, research is always in progress.

Learn more biomedcentral.com/submissions 